${ }^{8}$ Craske, J, Lancet, 1975, 2, 221.

${ }^{9}$ Dienstag, J L, et al, Annals of Internal Medicine, 1977, 87, 1.

${ }_{10}$ Villarejos, V M, et al, New England fournal of Medicine, 1975, 293, 1350.

11 Mosley, J W, et al, New England Fournal of Medicine, 1977, 296, 75.

12 Alter, H J, et al, Lancet, 1978, 1, 459

13 Tabor, E, et al, Lancet, 1978, 1, 463.

14 Knodell, R G, et al, Gastroenterology, 1977, 72, 902.

15 Knodell, R G, et al, Lancet, 1976, 1, 557.

${ }^{16}$ Dienstag, J L, et al, Lancet, 1975, 1, 765.

17 Szmuness, W, et al, New England fournal of Medicine, 1976, 295, 755

\section{Contracting in or contracting out?}

A new kidney donor card campaign was launched last week at Regent's Park Zoo by Mr David Ennals-helped by some women with transplanted kidneys who have had babies since their operation and by their families and two camels. This happy gimmick did at least show the human lineaments of the problem; but is the campaign soundly based?

The Government is going to publish a discussion document setting out the arguments for and against changing the Human Tissue Act 1961 to allow a contracting-out scheme. Because the matter is urgent (as it has been for the last 10 or 15 years), Mr Ennals has set out to double the number of cadaver kidneys while keeping the existing legal framework. In 1977 a total of 706 transplants were carried out, $22^{\circ}{ }^{\circ}$, more than in 1976; this is still well below the most conservative estimates of need. More kidneys are needed than the 1500-2000 patients each year who could benefit - the best results come when there is a reasonably close match. ${ }^{\prime}$ The supply continues to improve, but too slowly for those who can do no more than survive on dialysis-and for those who die.

The DHSS's campaign is directed at both the general public and the medical profession. For doctors a film will be available towards the end of the year showing the value of transplantation and the steps needed for removing and storing kidneys. The department is also setting up a working party to produce guidelines on the procedure for removing organs for transplantation. For the public there will be a massive distribution of kidney donor cards backed by general publicity such as posters and a TV filler film. One of the most productive measures would be to include a "kidney donor" section in the driving licence; but the practical problems are still being discussed with the Department of Transport.
As a result of past publicity and the 16 million donor cards distributed since 1972, the public is gradually becoming more aware of the need for cadaver kidneys, and this more intensive campaign (which will cost over $£ 100000$ ) may well accelerate $\underline{\underline{\sigma}}$ the process. But the apathy of doctors may be a greater 3 obstacle. This has two main causes-uncertainty about the interpretation of the law and dislike of approaching bereaved relatives. In 1975 the British Transplantation Society ${ }^{2}$ pro- $\overrightarrow{\vec{\rho}}$ posed a code of practice and statutory clarifications of the Act, which would help doctors on both counts.

The radical reform needed for any major improvement in $\frac{\bar{\omega}}{7}$ the supply of kidneys is a change in the law to allow organs from $\mathbb{Q}$ suitable donors to become available almost automatically. A recent debate in the House of Commons ${ }^{3}$ resulted in the $\vec{O}$ motion "that this House recognises the need to amend the Human Tissue Act to allow a 'contracting out' scheme. ..." $\vec{\omega}$ But before a Bill could be even introduced there is to be the $\partial$ discussion document-not before the end of the year-followed $\stackrel{3}{3}$. by discussion. The Government is not prepared to follow the $\overrightarrow{\dot{\sigma}}$ example of France, where a contracting-out system has $\overrightarrow{\vec{D}}$ preceded public education ${ }^{4}$-in fact doctors there are not yet taking advantage of the law to any extent for fear of arousing $\$$ hostility.

In Britain, though public sympathy is claimed for kidney $\vec{J}$ donor schemes, opinion surveys have given varıed results; in a small study in Manchester' $65^{\circ}$, were opposed to an opting- 을. out system even though reactions to kidney donation were generally favourable. A new survey has been commissioned by the DHSS, whose results should be known in the summer. But should the Government not be more actively leading public opinion and promoting the advantages of a contractingout system, provided that the safeguards are emphasised? For, given the built-in inertia of human nature, both the medical profession and the public need an essentially passive system, where willingness to donate organs is taken to be the norm and the onus is on the objectors to register their exclusion. In the long run a contracting-out system should also help to make organ donation altogether more matter-offact-like paying income tax (but with more chance of exclusion), part of the individual's contribution to society. And the bereaved could more often be helped by the knowledge of good coming out of their loss.

\footnotetext{
1 Lancet, 1978, 1, 591.

${ }^{2}$ British Transplantation Society, British Medical fournal, 1975, 1, 251.

${ }^{3}$ Hansard, House of Commons, 3 March 1978, col 831.

${ }^{4}$ Farfor, J A, British Medical fournal, 1977, 1, 497.

5 Moores, B, et al, British Medical fournal, 1976, 1, 629.
} \title{
.
}

